\title{
Female Objects and Feminist Consciousness for the Purpose to Awake Readers' Awareness: A Comparative Analysis between Angela Carter's The Bloody Chamber and Anne Sexton's Transformations
}

\author{
Liu Fenglin ${ }^{a^{*}}$ \\ ${ }^{a}$ Department of English, City University of Hong Kong, Kowloon, Hong Kong
}

\begin{abstract}
The female object, as a symbolic image created by male authors to reduce the threat brought by females towards patriarchy, has become a method to express male sexual and domestic fantasies. However, in the fairy tale adaptation by two mid-twentieth century female authors-Angela Carter and Anne Sexton, the female object is used to evoke feminist consciousness.

Although former studies have covered some feminism issues, for instance, the feminist awareness through the mirror image in Angela Carter's The Bloody Chamber, and the direct metaphors such as "doll" and "soap pop" which lead to female objectification in Anne Sexton's Transformations, little research has compared the distinctive psychological impacts that the narrative forms between the two mentioned texts have on readers.

In the first section of this paper, how both authors deconstruct the female stereotypes and how they reinterpret modes of female agency in the original Grimm's fairy tales have been examined. Based on the writers' perspective, the first section would also explore the expression of female objects in their works. As for the second section, I would mainly focus on the psychoanalysis of Lacan's mirror stages, and yet cover the awakening processes presented in the mirror images and symbols composed in the two adaptations. In the third section, the different narrative strategies utilized by Carter and Sexton in order to stimulate readers' responses towards feminist consciousness would be illustrated.
\end{abstract}

Keywords:

Feminism;

Female Object;

Feminist Consciousness;

Fairy Tale;

Psychoanalysis.

\section{Article History:}

Received: 19 September 2019

Accepted: 25 December 2019

Published: 01 February 2020

\section{1- Introduction}

Fairy tale has always been a part of the world's literature that could not be ignored. Its history could be dated back to ancient oral folk tales, which the narrations were relatively flexible, due to the different audiences. As Jack Zipes notes, those oral folk tales "were to be shared and exchanged, used and modified according to the needs of the tellers and the listeners" [1]. Therefore, as time goes by, when oral folk tales transformed into fairy tales, although some of the purposes and characteristics of its story narrating tradition has maintained - as both folk tales and fairy tales "ferret out [the readers and the authors'] deep-rooted wishes, needs, and wants and demonstrate how they all can be realized" [2] through their marvelous stories - to a certain degree, fairy tales also possess the features of socialization, for they gradually became a kind of moral lessons which follow the rules of the patriarchal society and "serve to acculturate women to traditional social roles" [3].

For instance, when the Brothers Grimm edited the oral folk tales into fairy tale collections, they modified the original tales elaborately to fit the Middle-class morality by "[weakening] once-strong female characters, [demonizing] female power" [4], while at the same time "[emphasizing] specific role models for male and female protagonists according to the dominant patriarchal code of that time" [1].

\section{* CONTACT: 18432182@life.hkbu.edu.hk}

DOI: http://dx.doi.org/10.28991/esj-2020-01207

(C) 2019 by the authors. Licensee ESJ, Italy. This is an open access article under the terms and conditions of the Creative Commons Attribution (CC-BY) license (https://creativecommons.org/licenses/by/4.0/). 
In order to control the "threat" brought by women to the patriarchal society, female figures in most of the Grimm's fairy tales, such as "Snow White", "Cinderella" and "Sleeping Beauty", have rapidly been displayed in silent positions. As Hélène Cixous and Catherine Clément once condemned, the "beauties slept in their woods...in their beds, in their glass coffins, in their childhood forests like dead women" [5]. Those heroines are often described as reticent figures who are waiting patiently for the princes' rescues. It seems that in these Grimm's tales, females' longing and waiting for males has been highly praised and exaggerated as the "romantic factor" of women's lives and the prelude to a "happily ever after" ending.

Similarly, a few decades later from the first publication of the Grimms' Fairy Tales, in Andrew Lang's fairy tale collections, female characters still had not processed a certain agency. For those carefully selected stories somehow strictly followed the power structure of Victorian society which "the institution of gender emphasises the 'maleness' of the world in which the narrative occurs" [6].

For instance, no matter in the "Prince Hyacinth and the Dear Little Princess" or "The Water-lily" of The Blue Fairy Book collected by Lang, the heroines have all been marginalized and forced into silence. It seems that being created as a princess, or a good girl who may probably become a princess for her femininity and domestic features, female characters in Lang's fairy book, "are literally asleep or in a trance like Sleeping Beauty or Snow White" [7]. Consequently, we could say that such fairy tale stereotype of female characters being trapped and being silenced while waiting for males' deliverance "is [exactly the particular archetype] that has always appealed to men, and it turns up again and again in their [literature]" [7].

Moreover, in the twentieth century, when fairy tales have been adapted by early cartoons of Disney, they are no longer considered as bedtime stories for children, but as a genre connected with commercial values. It is somehow clear that, as for the fairy tale adaptations by Disney, "profit mars their stories and their cultural heritage [... as productions of the imagination, they have somehow] been accomplished with the framework of the modern culture industry" [2]. To a certain degree, the marketing benefits forms by the social values of modern time, largely influenced the presentation of the fairy tale adaptations.

Although after the "First-wave Feminism", the females' appeals for power have been partially heard by the maledominated society, yet the social structure of the early twentieth century still remained in an unchangeable condition. As not only the social power "is associated firmly with the male and masculinity" [8], also the ruling gender which is considered as males still "actively structure the material-social relations in which all the parties are forced to participate" [8].

Therefore, under the fabric of such social condition, the early princess stories of Disney, for instance "Snow White" (1939), "Cinderella" (1950) and "Sleeping Beauty" (1959), somehow catered to the market orientation of the males' predominant society and helped to provoke a promotion towards the powerless and innocent female figure which appeals to the taste of patriarchal authority. Consequently, in that specific period, within the progress of creative media, "children are socialized or culturally conditioned by movies, television programs". In the early adaptation towards princess stories before 1960, Disney apparently passed the conception in which "every little girl is a princess" [9] to the targeted audiences which are considered as children and mostly girls, while at the same time hidden its commercial value directed by the male-dominated society beneath the "princess dreams".

Just as Elizabeth Harries points out, "little girls could not help but imitate" [10] those intentional messages provided by the patriarchy when they try to achieve their "princess dream" and gradually abandon their ability of independence. To become a princess, is somehow to become a "princess" structured by the patriarchal conventions.

However, when female authors realized such a premeditated "trap" set up for women by patriarchy in those wellknown tales and the relevant adaptations, they somehow started to write and present their own "essential self" in their adaptations of fairy tales, in order to help readers to discover the form of the power relationships of which females still being dominated by the patriarchy. Such condition somehow provided an opportunity for female members to discover their situations in the power structure while trying to strive "for the empowerment of [themselves]" [8], that is, to pronounce their own voices. Just as Cixous and Clément declares, "If women begin to want their turn at telling [the story], if they take the relay from men by putting myths into words...it will necessarily be from other points of view" [5]. Accordingly, the rewritten fairy tales by female authors later, in fact, matched with Cixous and Clément's goal, which is to form a kind of new writing that functions away from the former patriarchal stereotypes in the genre of fairy tales.

In 1971, not more than a decade from the first publication of Betty Friedan's The Feminine Mystique, which carefully discussed the reason and the impact of which "[t]he suburban housewife [became] the dream image of the young American women" [11], an American poet-Anne Sexton published a collection of her fairy tale adaptations, entitled Transformations. As a kind of criticism to the "early moral education handbook"-Fairy Tales, which intended to educate girls obeying the patriarchy and enhancing their domestic abilities, the theme of Transformations, to some extent, shows a kind of echo to Friedan's critique towards females' domestic situation in the late twentieth century's American society. 
Meanwhile, eight years later, also influenced by the second wave of feminist movement, a British novelist who once won the "Somerset Maugham Award"-Angela Carter, created a short story collection The Bloody Chamber. The book as well focused on the gender issues in those original fairy tales, to illustrate the condition of the contemporary females under the control by the patriarchy.

Although in past researches, some feminist scholars, such as Jack Zipes, Donald Haase and Marcia K. Lieberman, focused on the fairy tale adaptations by female authors, little research has been conducted on the direct comparison between Angela Carter and Anne Sexton, especially on their narrative strategies. Not only are the writings of the two authors in different genres, so that researchers are more likely to analyze Carter with other novelists while classifying Sexton in the category of poets. As the short stories of Carter usually follow an even narrative form which creates a kind of chronology and sequence, whereas Sexton's poems, composed by poetic language, somehow would break down the linear narrative form, because "[p] $]$ oetry provides its readers, then, with what may be called a language of experience, an idiom, of which the unit may be an entire complicated emotion or incident. The language is not the language of prose" [12].

In addition, the apparently different themes in their revisions as well left space for researching towards their similar attempts by materializing female members. For Sexton focused more on the feminine social values under the modern consumer society, whereas Carter tended to deconstruct powerless female figures and reshape them into entirely newwomen who may also possess characteristics of masculinity at the same time. Furthermore, among both of the adaptations, the metaphorical elements which implied the processes of mirror stages towards females' selfconsciousness, as suggested by Jacques Lacan, as well, haven't been compared in those former researches on Sexton and Carter.

Therefore, due to these factors above, this paper may focus on the comparison between themes, symbols, and metaphors, all of these similar narrative strategies utilized in Carter and Sexton's works, in order to fill in the blankness in those previous researches, as well as illustrate the method used by both authors in awakening readers' consciousness towards the conditions of females' survival in the male-dominated society and their lack of agency.

Just as Salman Rushdie mentioned in his introduction to Angela Carter, that she "opens an old story for us, like an egg, and finds the new story, the nowstory we want to hear, within" [13]. Rushdie's idea correspondingly meets the thought that Richard E. Morton once claimed towards Anne Sexton's narrating strategy. For Morton notes, "each of [Sexton's] passages are oblique rather than explicit; it is the reader who interprets the sexual direction of a story to which the poet has given no particular direction" [14]. Rather than making a dedicated critique towards the patriarchal authority, Sexton is more likely to describe a kind of "social norm" by placing several examples which implied the conditions of female members in the society inside her poems, in order to invite the readers to explore the fact of females losing their agency under the control of the patriarchal society.

To some extent, both Carter and Sexton's transformations of fairy tales are a process of deconstruction and rebuilding rather than simply retelling. They never give their rewrite work a fixed meaning but compose it to be a kind of reflection and criticism of the old versions by creating unease, ambivalence and subtle imageries, so as to attract readers' attention and thus finally raise their awareness towards female issues. Hence, this strategy overlaps with what Steven Jones summarized in his view of reader-response criticism: "A story means what its readers and listeners take to be its meaning; its significance is reflected in their response" [15].

It is worth noting that, both authors also mapped out the narrating strategy of using the female object to stimulate female readers who still live under the shadow of patriarchal society unconsciously. For instance, in the reinterpretation of "The Bluebeard", Carter tends to objectify the female figure into a victimized ideal under masculine power at the very beginning. Mary Kaiser believes that the nakedness of the bride under Bluebeard's gazes undoubtedly debased her into a pornographic object, as when the bride gazed at herself from her husband's perspective through the mirrors in their bedroom, she suddenly realized that she "has been reduced to an unaccommodated body" [16]. It seems that as for Blue Beard, the young bride is no different from a female object with her value limited in an innocent appearance and her virginity. Similarly, in Sexton's Transformations, those once "idealized" female figures in the original Grimm's tales have also been materialized by the author without any hesitation. However, instead of using the psychological descriptions in forming a notion that female has been objectified by males, Sexton is more likely to depict female characters straightforwardly into an object.

By using such strategies showing the condition of female materialization, to a certain degree, Carter and Sexton exactly planned to place the audiences in a correspondingly impersonal perspective, so that the readers could realize the powerless and corporeal position of the female under the patriarchy through those explicit metaphors.

Even so, in their attempt to reinterpret the fairy tales in a feminist voice, there still exists an obvious distinction between Carter and Sexton's narrating styles that have not yet been mentioned in any previous research. As Carter is more willing to show the psychological awakening processes of female protagonists, whereas Sexton merely maintained those female figures under the condition of ignorance just like pieces of meat. Such particular difference which to some 
extent, not only influenced people's acceptance and understanding of both authors' works but also led to an empty space towards female studies in the genre of fairy tales.

\section{2- The Strategies in Composing Fairy Tale Reproductions}

Arlene Croce once claimed that in the literature created by the patriarchy, "the Muse is only a man speaking through a woman herself" [17]. Female characters under the narration by male authors often conveyed the conception of male fantasies, and so are those female figures in fairy tales; for instance, "Cinderella", "Snow White" and "Sleeping Beauty", as all the princesses in these stories are beautiful and innocent and are waiting for males' protection and rescue.

It is well known that as one of the conventional characteristics of the earliest fairy tales, female figures were created as "either beautiful, slumbering young girls or powerful, usually wicked and grotesque older women" [10]. Such separated and polarized stereotypes eventually led the ending of the story into the triumph of the beauty and the failure of the Gorgon. It seems that in former fairy tales, the woman who has the qualification of "good-temper and meekness are so regularly associated with beauty, and ill-temper with ugliness" [3].

To some extent, the obvious separation above seems to make the stories easier to understand, because those fairy tale figures are like wearing masks and could enable the readers to tell good from bad at the first glance, but on the other hand, it also provides a didactic function which guides readers to the domestic fantasy towards women under the males' perspective. As in those fairy tales, the girl who is capable in the abilities of housekeeping, or the one who maintains in a pretty and mild situation would often achieve the awards of getting rich (usually through marriage) or become a princess.

While reading those tales, women readers, especially young girls, are indeed being educated unconsciously to keep their beautiful appearances and docile traits in order to be well-prepared for their marriage and their household lives under the direction of androcentrism. As in those original tales, only the beautiful and mild female figures who were suitable to the males' taste of an "angel in the house" [18] could achieve a good fortune.

However, in the rewritten fairy tale works by the two contemporary feminist authors-Angela Carter and Anne Sexton, the stereotyping tendency of the polarized female figures in the original fairy tales has been maintained to some extent while acting as a way to stimulate readers' response towards feminist awareness. Though the genres of the two authors' works are different, the narrative strategies used by them indeed share similar characteristics that could not be ignored.

\section{2-1- Female Objects in Breaking the Conventional Narrating Form}

In Transformations, Anne Sexton inherited the traditional stereotype of the "innocent virgin" in the former fairy tales. Accordingly, Sexton's usage of such specific category of female figures somehow shows a kind of parody and irony towards the myth of the eternal feminine. The notion of the eternal feminine, as illustrated by Simon de Beauvoir in The Second Sex in 1949, accordingly identified the existence of the individual female as being classified into "Others" by males. To some extent, it is clear that the condition of such specific myth presents a sense of which females have been socially constructed by the patriarchal conventions, as they "are told not that Femininity is a false entity, but that the women concerned are not feminine" [19]. Therefore, as the notion of the stereotypically feminine woman, under the construction of the patriarchal society, according to Sandra Lee Bartky, "is defined in terms of what she isn't than what she is: what she isn't — that is, what she lacks—is what is traditionally regarded as the masculine" [20]. If not maintaining in a domestic and duteous position which is being silenced inside the kitchen and boudoir, the female member would be considered as the one who lost her femininity by males.

Therefore, in Transformations, as for the characteristics of those innocent female roles, Sexton somehow deliberately exaggerated the notion of the eternal feminine while situating female figures into correspondingly silent positions from the beginning until the end. It seems that all our familiar female fairy tale figures in Sexton's version acted like phantom dolls - beautiful but possessing little right to speak. Consequently, it is acknowledged that in the three love poems of Transformations, the "doll" image has been implanted so as to depict the condition of female protagonists. For instance, in the first stanza of "Snow White", the princess has been metaphorically linked with the statement of a lovely virgin "rolling her china-blue doll eyes/ open and shut./ Open to say,/ Good Day Mama,/ and shut for the thrust/ of the unicorn" [21]. These lines, if they have not been associated with Snow White, would somehow be considered as the description of an Enchanted Doll who owns the meaningless and mechanically repetitive behavior when its eyes turned open.

Such typical lines which directly format female characters into seemingly silenced doll-like creatures, also appeared in the last poem ("Briar Rose") of this collection. In order to form an exaggerated effect of females being shaped by the patriarchal society as a silenced doll-like figure, Sexton particularly places the Sleeping Beauty into an even more tough situation in which her actions were restricted by her father (one of the patriarchal representations). In the first stanza, echoing to the setting of the father's overprotection towards Sleeping Beauty in the original fairy tale, Sexton begins the poem by describing a consequently ambivalent relationship between a father-like figure and his "daughter". The narrative structure used in this specific episode is very worth noting, as the first half of this stanza, is Sexton's third- 
person narration towards the girls living condition. These lines somehow provided a sense of which the girl is still being treated as a two years old child who is "learning to talk again" [21]. Meanwhile, when it comes to the second half of this stanza, the tune suddenly transformed to the first-person narrative which stands at the father's perspective, referring: "little doll child,/ come here to Papa./ Sit on my knee" [21]. To a certain degree, in the first stanza of Sexton's "Briar Rose", the girl is remaining in a silent situation - like a doll, or a child who could not speak-because not only her surviving condition is described to the readers by the poet or any other person that is apart from herself, but also, we could discover that, the only protagonist who possesses the right to pronounce in this stanza is the father figure, which is a male.

Moreover, in the main part of this poem which retells the story of the "Sleeping Beauty", Sexton added two correspondingly repetitive sections inside, which also echo the repetitive lines in "Snow White", as mentioned above. The first section appears when the prince kisses the Sleeping Beauty as a symbol of rescue in the original fairy tale, thus, "she woke up crying:/ Daddy! Daddy!" [21]. Also, by the end of the poem, Sexton somehow repeated this factor of the Sleeping Beauty that "if you kissed her on the mouth/ her eyes would spring open/ and she'd call out: Daddy! Daddy!" [21]. Instead of celebrating for the freedom after escaping from her father's control, the heroine accordingly kept herself in a subtle situation - as she is calling her prince "daddy, daddy". To some extent, the notion of "father", could be considered as a symbol of the patriarchy, because in the conventional conception of "family", father-as is always the one who situates in the dominating position. The Sleeping Beauty in Sexton's version, as long as she refers and requires the prince to become a kind of "father" figure whom she escaped from, therefore, she is exactly returning to the patriarchal society and initiatively giving up her agency.

Such condition somehow presents as a kind of reflection towards females' ignorance of their agency being frustrated by the patriarchy. Just as Janet Saltzman Chafetz noted, "Gender ideologies are more stable and resistant to change" [22]. Consequently, we could say that, apart from the material appearance of female characters who are associated with the literal meaning of the "doll" in Sexton's poems, to some extent, the heroines could also be referred as objects without their own abilities of thinking, because of their "conditional reflex" of the repetitive obedience to the patriarchal authority.

Furthermore, the actions of the patriarchal authority in Sexton's poems, also help to amplify the materialization of female members. In the poem "Snow White", when Snow White ate the poisoned apple, she turned into the condition of suspended animation, "[the dwarfs] washed her with wine/ and rubbed her with butter/.../ [and] she lay as still as a gold piece" [21]. Moreover, within the pride of "possessing" Snow White's beautiful appearance, the dwarfs "made a glass coffin/.../ so that all who passed by could peek in upon her beauty" [21]. The glass coffin, as Philip McGowan noted, is "for the display of this example of aesthetic if not intellectual perfection" [23]. From the descriptions above, we could discover that the dwarfs, although narrated by Sexton as "little hot dogs", still present the identity of males and stand on the side of patriarchy which takes the female as the accessory for decoration. Therefore, by the actions of the dwarf, Snow White has somehow been treated as a fetish, a non-life object placed in the showcase that has been "employed to still and silence, bind and dominate [situation]" [24].

To some extent, although it follows the original storyline of "Snow White", Sexton's poem somehow exaggerated the fact of which female is being treated as a kind of sexual object that would lead to male gaze. As long as Snow White is being displayed to the passerby, therefore, she is then suffering from a disposition of materialization, and is being otherized by the patriarchy. The existence of Snow White when she situates inside the glass coffin is somehow shown "as sex object, as object of the male gaze [...] despite the intentions of the woman herself" [25]. Such condition accordingly overlaps with what Simon de Beauvoir once indicated: "to pose Woman is to pose the absolute Other, without reciprocity, denying against all experience that she is a subject, a fellow human being" [19]. With the existence value being objectified, the Snow White in Sexton's poem, is nothing to the patriarchal authority except her beautiful body.

Consequently, Sexton's terminology in describing female's condition somehow brought up a sense of indisposed feeling towards the readers. However, the reason for Sexton to compose the poem in such a way of which female characters have been seriously objectified without any agency left, as she mentioned in an interview, that "[poems] should be a shock to the senses. It should almost hurt [...in order to] make us become more aware" [26]. Indeed, in those poems in Transformations, Sexton tries to provide a sense of unease towards the readers and expects more on the awakening processes happened on her readers. To some extent, Sexton's poems did not illustrate the conceptions of feminism; however, the issues she wrote in the poem eventually shocked her readers and stimulated their notice on females' social conditions when reading it.

However, in Angela Carter's reinterpretation of those fairy tale works, the categories of female characters, to some extent, are slightly different from that of Anne Sexton's. In the collection, Angela Carter tended to narrate her female protagonist in a correspondingly complicated way, as most of Carter's short stories such as "The Bloody Chamber", "The Tiger's Bride" and "The Courtship of Mr. Lion" all presented the evolution processes of an innocent maiden transforming into a mature and independent individual under the patriarchal society. 
To some extent, it seems that, those females all possess double personalities. They are the combination of the innocent maiden and also the feminist with a sober mind. Accordingly, they are both silent and talkative. For instance, in "The Bloody Chamber", the young bride has been created as a naïve and introverted girl. She seldom speaks and expresses her desire and her will to her husband-Bluebeard when they first get married. Such circumstance is not only caused by her characteristic as a female under patriarchal society, but also by the whim of Bluebeard, because he encourages her to be tame and pure-minded.

Although silenced in their appearance, Carter somehow shows a lot of mental activities of her heroines to the readers. For example, in "The Tiger's Bride" the heroine remains silent to the Tiger before she has been taken away from father. However, when gradually she accesses the Beast and discovers his true personality hidden beneath the seemingly masculine appearance, she becomes less afraid of him and feels more on the female agency that she gradually possesses.

Therefore, the inner monologue of the girl shows a rather direct indication of her transforming processes which not only enables readers to get closer to the figures, but also point out a way to those awakened females, as they shall make their own decisions and should challenge the males' dominant power so as to survive in the modern society.

\section{2-2- Female Consciousness in the Processes of Awakening}

Cristina Bacchilega once illustrated that the postmodern reinterpretation of the fairy tales "hold mirrors to the magic mirror of the fairy tale, playing with its framed images out of a desire to multiply its reflections and to expose its artifices" [27]. To some extent, what Bacchilega means is the rewritten work provided a reflection and carried a sort of implied meanings towards the original Grimms' fairy tale, yet to express the author's intention through the adapted contexts towards the original stories. Indeed, in Carter and Sexton's version, both adaptations elucidate and disclose the inequality of the power structure under the patriarchal sphere and use the female object as a narrative strategy in order to awaken the readers' awareness towards females being silenced and marginalized by the male-dominated society.

Such condition, as for Angela Carter, the conception of female objectification in her short stories' collection somehow is linked with the utilizing of reflections. The mirror reflections, the eye reflections, and the symbolic reflections are all the primary elements which composed the image system in The Bloody Chamber. Accordingly, Carter placed progressive stages of self-recognition in the different processes of the heroines' transformation. They looked into themselves through the mirror, through other people's eyes while figuring out their being materialized by the patriarchy. To some extent, the awakening of the feminist awareness is combined with the heroines' gaze back at their own reflection.

For instance, in the story “The Bloody Chamber”, there are three steps of mirror stage progress towards the heroine's feminist consciousness. A day before the wedding of the girl and Bluebeard, they went for an opera-Tristan. Sitting in their loge in the opera's interval the girl gazed herself through the mirror and through Bluebeard's eyes in the mirror:

"I saw him watching me in the gilded mirrors with the assessing eye...of a housewife in the market, inspecting cuts on the slab...When I saw him look at me with lust...I caught sight of myself in the mirror. And I saw myself, suddenly, as he saw me" [28].

In the mirror reflection, the heroine recognized herself being objectified as a slab of meat and being defined as the "other" who was marginalized and distinguished from the patriarchal authority, for the first time. The behavior of the heroine looking at her reflection following the gaze of the Bluebeard in the mirror is similar with the circular process which Jacques Lacan mentioned; the subject "has [herself] seen appear in the field of the Other, from the Other coming back" [29]. This action accordingly posited her at the male's perspective, in order to observe the condition of being a female object.

Moreover, the discovery of the girl somehow also matches up with what Ewa Glapka once declared, that when a female "compar[es] herself to meat... [the] consumption in which her subjecthood is annihilated as she is reduced to a passive, anonymous and voiceless body" [30]. To some extent, Carter is using the mirror reflection and the heroine's discovery of the first stage to illustrate a kind of social phenomenon of which female members' statuses are reduced by the patriarchy when being materialized into a voiceless object.

After their wedding, when coming across the first stage of noticing her objectified self under the patriarchal society, the girl confirmed herself as being the personal property owned by her husband, by terms of physical meanings. The mirrors surrounded in their bedroom reflected white lilies and the young bride into countless and numerous images and finally overlap with each other. When the girl looks at her husband who is gazing at her through the mirror-as Lacan indicated towards the infant's discovery of the "self" - she then discovered that she is no difference with all those lily flowers displayed in their bedroom. To a certain degree, the implied meaning hidden behind the flower image, somehow also provided a metaphorical conception that the female body of the girl is being materialized as one of the pure white flowers in a silent and decorative position. 
After the verification of herself being objectified as the lily flower, the young bride realized "it must have been [her] innocence that captivated [the Bluebeard]" [28]. However, instead of transforming herself into a powerful female with the right to pronounce, the girl accepted the fact and chose to cater to the fantasy of the Bluebeard. Just as Karen Horney declared, "women have adapted themselves to the wishes of men and felt as if their adaptation were their true nature. That is, they see or saw themselves in the way that their men's wishes demanded of them" [31]. The girl in "The Bloody Chamber" also claims that "[her] naivety gave him some pleasure made [her] take heart" [28]. She somehow considered her obedience to the patriarchy as the natural way of the human society, yet she never expected to confront males' dominance authority until she opened the secret chamber of the Bluebeard and felt that her right to subsistence is being deprived.

Therefore, when the Bluebeard is finally killed by the bride's mother in order to save her daughter, the bride surprisingly chose to marry a blind piano tuner who was usually not concerned as a suitable marriage partner. Since, in the fairy tale, "marriage is associated with getting rich...Good, poor, and pretty girls always win rich and handsome princes, never merely handsome, good, but poor men" [3]. The ending according to Elaine Jordan, "the bride has already been too much seduced by seeing herself as 'not like that,' one who knows her in his heart, and can appreciate her skill as a musician" [32]. Although without any substantial reflection of the heroine in the mirror, the story is somehow ended by the last stage of the "mirror reflection"- the image reflected in the piano tuner's heart. As the heroine noted, "I know he sees me clearly with his heart" [28]. The monologue of the girl at the end of the story, consequently illustrated a sense of independence, because she no longer needs to define and locate herself from the perspective of patriarchy, and since the blind piano tuner treats her as a musician, the conception of female objectification collapses immediately.

However, different from Angela Carter who arranges the symbolic meanings of the reflections yet shows the processes of the heroines' self-discovery from the objectification to readers, Anne Sexton tends to express the phenomenon of materialization by using a direct narrative method-enumerating material images in the poems. For instance, in Sexton's version, Snow White's "arms and legs made of Limoges, lips like Vin Du Rhone" [21]; the prince in "Cinderella" "began to feel like a shoe salesman" [21] when finding his lover, and the twelve dancing princess "danced like taxi girls at Roseland/ as if those tickets would run right out" [21]. By linking the storylines of fairy tales with those characteristics of consumer society, Sexton's poems indicate the fact that "women receive their value, as they pass from the state of nature to the social object. This transformation of women's bodies into use values and exchange values inaugurates the symbolic order" [33], because exchanging female objects as commodities still exists as a kind of norm rooted in people's subconsciousness nowadays.

As Lionel Bailly noted, "in the Mirror Stage, the Subject is the active mind that produces the concept of itself as the other in the mirror; but it cannot know (or recognize) itself" [34]. Unlike Angela Carter whose reinterpretations mainly focused on the fairy tale heroine's self-recognition through the mirror stages and the awakening of feminist consciousness, the Subject of Sexton's poems accordingly could be considered as the readers who were benumbed by the patriarchy and accepted the submission of females as a daily routine. In other words, Sexton's Transformations itself is the image of the mirror stage provided to the social audiences.

Instead of presenting the self-discovery processes of female characters, provoking the reader's consciousness towards the lack of females' agency seems to be the first priority of Sexton's attempt when writing those poems. Take the poem "Snow White" as an example. In the poem, the mirror is a significant image appears to both Snow White and the queen. It is acknowledged that in the original Grimm fairy tale, the "magic mirror" is shaped as the "truth speaker", and the cause of the queen's "untrammeled sexual jealousy, which tries to ruin others" [35]. Nevertheless, it also functioned as the element which pushes forward the storyline. However, in Sexton's adaptation of this original fairy tale, the magic mirror is not limited in the narrow notion of the patriarchal perspective towards females, but it possesses the symbolic meaning of the females' ignorance to their own social condition and their blind obedience to the patriarchal structures.

In Sexton's version, when Snow White defeated the step-mother and punished her to death, she "[rolls] her chinablue doll eyes open and shut/ and sometimes referring to her mirror/ as women do" [21]. Such ending with the repetitive behavior of the Snow White to the queen, as Caroline King Barnard Hall mentioned, "Sexton's Snow White remains naïve...since she now 'refer[s] to her mirror,' she has become in all ways the new queen" [36]. As the magic mirror to some extent symbolizes the perspective from the patriarchal authority, we could discover that Sexton is creating a kind of metaphor to emphasize that no matter the Snow White or the evil queen, they could somehow be mixed and considered as the same woman situating in the different age groups that have been objectified as males' fetish and would merely refer to the desires of the patriarchy, yet have little consciousness towards their personal right and fate as a female. Accordingly, Sexton's Snow White matches up with Lacan's opinion of "Meconnaissance", as Bailly illustrated, "[Snow White — the subject] is completely blind to the object [—-her objectified 'self']" [34].

As Sexton indicated in an interview that the poetry "should be a shock to the sense" with the metaphors which could "make [the readers] become more aware" [26]. Therefore, the implicit images in her poems amplified the fact that females are unaware of herself being materialized and considered as males' fetish, shows that the "fetishism 
transformation ambiguity and uncertainty into something knowable and certain and in doing so snuffs out any sparks of creativity that might ignite the fires of rebellion" [24].

From such narrative strategies as to evoke readers' response, we could discover that, the lack of agency of Sexton's heroines somehow provided the agency of self-awareness in the form of mirror stage to the readers. According to Jane Gallop, "the mirror stage itself is both an anticipation and a retroaction...[as] after it, the subject's relation to himself is always mediated through a totalizing image that has come from outside" [37]. The fairy tale figures in the seventeen poems of Transformations, to some extent, present as the images shown as the reflections of the readers (the subjects) in the natural reality. Just as Sexton notes in the first poem of this collection: "let me present to you this boy./ He is sixteen and he wants some answers./ He is each of us./ I mean you./ I mean me" [21]. Therefore, from the lines above, we could capture that, the fairy tale characters' self-consciousness towards the female objects is not what Sexton expected to illustrate, but the uneasy feeling of the readers which leads by the poems' mirror effect is the core attempt which Sexton arranges to manage in her poems. Just as what Jacqui Halson declared, "[i]ndividuals must see that the cause of their personal experiences is oppressive social relations" [38]. Only if the readers in contemporary society noticed their own constrained situations, could they ultimately appeal to the equality in agency between different genders.

\section{2-3- The Appeals towards Female Agency}

In general, according to Sheldon Cashdan, the genre of feminist tales "uses a fairy-tale format to suggest ways in which stereotyped images of women - and men — can be reshaped through fantasy" [39]. In breaking the conventional fairy tale structure of the "once upon a time" beginning and the "happily ever after" ending, both Carter and Sexton made a great effort in their narrative strategy of the adaptation.

As Angela Carter claims, "I would regard myself as a feminist writer, because I am a feminist in everything else and one can't compartmentalise these things in one's life" [40]. Situating herself as a feminist, to some extent, Carter retorted the "dramatic rescue" of the original tales, in which "men come along to rescue women who are in danger of death, or are enslaved, imprisoned, abused, or plunged into an enchanted sleep which resembles death" [3]. For example, in "The Bloody Chamber", the heroine has neither been saved by her brothers nor her lover (the piano tuner), but by her mother who broke the gate and rushed forward like a wild creature. It seems that, what Carter wants to express is: the first step for females achieving their agency is to stand on their own feet so as to fight for their personal rights.

Besides the remodeling of the classical rescuing plot, the female figures in Carter's The Bloody Chamber also chose to make decisions for their own fortune instead of executing passive obedience to the patriarchy. Such consequences could be observed in "The Tiger's Bride" - Carter's adaptation to "Beauty and the Beast". This specific short story begins with the stereotypical tradition of which the beauty's father lost his beloved daughter to the Beast; to a certain degree, Carter rearranged the male-female relationship under the structure of the patriarchal convention, as father owns the power to charge his daughter's fortune.

However, as for the main part of the story, Carter transforms the plot as the processes for the heroine figuring out her situation under the control of the patriarchy. It is after the mirror stage transformation of her consciousness in discovering that she has been objectified and treated as a commodity actually by her father. She therefore refused to return to him whom somehow appears to be the symbol of the patriarchal society, but claimed that she "will dress [the machine maid] in her own clothes, wind [the maid] up, send [the machine] back to perform the part of her father's daughter" [28]. The decision of the heroine ironically disclosed the fact-what patriarchal society really needs is not a human female, but the "machine maid" who refers as a female object that attaches with the functions of obedience, decoration and domesticity.

Similarly, distinguished from the customary plot of the Grimm fairy tale in which the evil magic would vanish immediately and the story usually ends up with the "happily ever after" marriage of the two protagonists, Carter eventually presents her reinterpretation in the way which the heroine transformed herself into a beast with an open ending full of symbolic meanings. Apparently, the last line of this typical story-"[The heroine's] earrings turned back to water and trickled down [her] shoulders; [She] shrugged the drops off [her] beautiful fur" [28] — shows a tendency of the heroines abandonment to the human society accompanied by the patriarchal ideologies, because of her transformation into a wild animal. According to Janet Chafetz, gender ideologies "are typically embedded in yet broader belief systems, especially religions, along with overarching sociopolitical and cultural views of the world" [22]. What Chafetz indicated towards such conception of gender ideology, is somehow the stable structure of power relationship between different genders which is still under the control by the public sphere created by the patriarchy. Therefore, in Carter' s short story, specifically, when the beauty finally transforms to a tiger, she is not limited in the social discourse of "woman" anymore but becomes a newly born creature who possesses diverse possibilities towards her own fortune. She became, consequently, an outsider of the patriarchal hierarchies in gender issues. Also, the earring image, provides another metaphorical effect that works in concert with the beauty's physical transformation yet evaluates the condition of females achieving their right of autonomy. The arrangement of this consequently subtle symbol, just as Murray 
Knowles and Kirsten Malmkjær once claimed, "[i]t is not necessary to explain the social structure in great detail in fairytales, because, as it is our own, it is familiar and available for metaphorical representation in fairy tale" [6]. Therefore, as in Carter's adaptation, when the diamond earrings (usually reveal as the fetish and decorative consumption that the patriarchal authority added to the female body) turn into water drops along with the heroine's transformation, the patriarchal constraint towards female members ultimately vanished, because the female figure in Carter's version no longer needs to care about her "beautiful" appearance according to the rules set up by the patriarchal authority. Generally speaking, in Carter's version, the Beauty figure is never a "Beauty" defined by patriarchy anymore. Indeed, she possesses her autonomy, and could decide what she truly wants to be.

To some extent, Carter's new illustration towards the ending of the fairy tales could be considered as a kind of defamiliarization towards the well-known Grimm's tale, because the narrative strategy in evoking feminist consciousness accordingly breaks down conventional storylines of the formal tales. As those new females created by Carter do not blindly aim to present as the oblique role models which indicate the morality that "black is black and white is white. There are no in-betweens" [39]. Consequently, the female characters created by Carter presented the essence of females, or we could say, the essence of human being, as they are described as complicated creatures that could process many characteristics.

Likewise, the modernity elements appear in Carter's adaptation also provoke for the sense of defamiliarization. For example, in "The Bloody Chamber" and "The Courtship of Mr. Lion" the transportations are both trains and cars, and there are even modern facilities as telephones and taxis among the storyline. Although, these modern settings enabled the ambiguous time setting of the formal fairy tale clearer and also presented a seemingly familiar sense towards our nowadays social environment, as if we feel that the plots occurred right beside us, the purpose for Carter using such narrative strategy, just as Alison Lee once indicated, is that "Carter's 'alien' viewpoint [...indeed defamiliarized] the familiar cultural artifacts she explores, and it encourages her readers to look at ordinary things in unusual ways" [41]. It is because of our familiar sense towards the patriarchal consumption hidden beneath the social structure nowadays, that unconsciously "we have no stable hold on ourselves and no stable hold on reality outside ourselves...in the act of interpreting [the reality] we partly invent the thing we are representing to ourselves" [42]. Therefore, because of these factors, we unconsciously consider the gender structure composed by patriarchal ideologies as a social norm.

Accordingly, as a feminist writer, Carter's attempt of evoking feminist consciousness consequently leads to positive effects to the readers yet to promote their responses in pursuing females' rights. Just as what Aidan Day illustrated, "the principle of fiction-making [is] moreover, a point that embraces the reader, indeed the whole of humanity" [42]. The strategy of alienation in Carter's The Bloody Chamber, therefore, supplied an opportunity for all of the readers to defamiliarize both their social life under the structure of patriarchy as well as the original Grimms' fairy tales, in order to form a new conception about gender and female object through the transforming processes of the heroines' feminist awakening.

Similar with Carter, Anne Sexton is also providing a sense of "Alienation" by linking the fantasy without the concept of time to the daily life of the contemporary society. However, the method which Sexton used in the defamiliarization processes is slightly different from that of Carter's, as Sexton defamiliarized both the form and the content of the formal fairy tales.

Take the poem "Cinderella" as an example. Sexton's version of this well-known story, compared with the original Grimms' fairy tale, to some extent, appears to be a more personal and socialized article. As in the first four stanzas of this poem, Sexton has not directly come to the reinterpretation of fairy tales, but she starts with a brief rundown of four "That stories" which indicates the lucky fortune of the ordinary person suddenly became a millionaire or ascended in an upper-class. Accordingly, such arrangement provided a double metaphors towards Cinderella, because on the appearance, those "that stories" describe the reversal of one's destiny; however, when we closely read the lines, we could notice a kind of social content of operation arrangement, because in the four events, the former career of the two female figures are constructed by domestic characteristics. As the nursemaid before attracted the attention of a wealthy man, her daily life is surrounded by diapers, while the charwoman remaining in the duty of household, before she achieved a large amount of money which could somehow change her career and living condition. Such factors in Sexton's poem somehow indicate the females lack of agency also in careers of the modern society, which according to Peta Bowden and Jan Mummery: "the accompanying designation of the public sphere as the location of man and their activities, and the private sphere as that of women, enshrines men's dominance in social life" [43].

Moreover, inspecting the realistic features of the social condition, the endings of the poems "Cinderella", "Snow White", "The White Snake", and "Briar Rose" also contribute to the narrative strategy of Alienation, not only because all these poems end up with a considerably ironic description and critic towards the fairy tale figures' lives after marriage, yet also provide the reader a new perspective in looking back towards the surrender of females to the "social norm" set up by patriarchy. 
For instance, in the last stanzas of those poems, Sexton raised up with a kind of satire strictly to the conventional structures of the patriarchal society. For instance in "The White Snake", the marriage of the king's servant and the princess, forced them to appear as if "they were placed in a box/.../ living happily ever after —/ a kind of coffin,/ a kind of blue funk./ Is it not?" [21]. In addition, after the seemingly beatific marriage, Cinderella and her prince live "like two dolls in a museum case" while Snow White returns to her characteristic as a doll.

It is acknowledged that in the original Grimms' fairy tales, "the stories can be described as being preoccupied with marriage without portraying it; as a real condition, it's nearly always off-stage" [3]. It seems that the after-marriage life is always the incomplete part that fairy tales avoid involving, because the didactic purposes of taming females in possessing the features of domesticity and innocence have already been achieved when the heroine has been saved by the princess or her lover after a long term of suffering and longing. However, the problems that may be embedded by the time of the male dominance marriage in the patriarchal society have been totally ignored. Therefore, just as Hall mentioned to illustrate Sexton's "Briar Rose", "the happy future of these and other heroines is really a kind of living death" [36].

Within such narrative strategy, to some extent, we could say that both Carter's and Sexton's adaptations to the formal fairy tales are "a challenge to traditional consolatory myths about the role of women-embodied in traditional interpretations of fairytales: women who seem to connive in their own servitude" [44]. As both the two rewritten works not only illustrate the commercialization of female members in this materialistic age, but also indicate a sense of helplessness of both men and women under the conventional ideology of the patriarchal society. Also, in the two adaptations, another conception which has been clarified by the two authors is: although people struggled for female right and appeal to the power equality between different gender, in modern society, it is still the social structure under the direction of patriarchal conventions that appears as the giant boundary and the limitation to the gender consciousness of both males and females.

\section{3- Conclusion}

Therefore, as Sexton once announced in an interview, "what [a writer] should do-[is to] move people to action" [45]. To some extent, although it seems to materialize female figures into objects on the very surface, by providing a sense of mirror effect, nearly all of the adaptations towards fairy tales by Carter and Sexton, aim to promote their reader's awareness and response towards social affairs. Through the actions of Carter's heroines gazing back to themselves and through the unease image furnished by Sexton, readers could be available to discover an invisible mirror reflecting their own condition operated by the patriarchal notion, yet ultimately take action to resist the unequal treatment of being objectified as a thoughtless decoration and being tamed by domestic factors. Similar to Sexton's opinion, Adrienne Rich also indicates that literature is "more than music and images; [but] also revelation, information, a kind of teaching" [46]. To a certain degree, the reinterpretation written by Carter and Sexton, could be defined as a kind of teaching and specifically a kind of potential encouragement—no matter to female or male readers-as it facilitates and emphasizes the significance for females to appeal for the agency in order to truly possess their "selves", and their real voices.

\section{6- Conflict of Interest}

The author declares that there is no conflict of interests regarding the publication of this manuscript. In addition, the ethical issues, including plagiarism, informed consent, misconduct, data fabrication and/or falsification, double publication and/or submission, and redundancies have been completely observed by the authors.

\section{7- References}

[1] Zipes, Jack. "When Dreams Came True: Classical Fairy Tales and Their Tradition.” Choice Reviews Online 37, no. 02 (October 1, 1999): 37-0754-37-0754. doi:10.5860/choice.37-0754.

[2] Jones, Steven Swann, and Jack Zipes. "Breaking the Magic Spell: Radical Theories of Folk and Fairy Tales." Western Folklore 41, no. 3 (July 1982): 240. doi:10.2307/1499668.

[3] Lieberman, Marcia K. “'Some Day My Prince Will Come': Female Acculturation through. The Fairy Tale.” In "Don't Bet on the Prince: Contemporary Feminist Fairy Tales in North America and England.” Edited by Jack Zipes, 185-200. Aldershot, Hants: Gower, (1987). doi:10.1525/aa.1987.89.2.02a00840.

[4] Haase, Donald. "Fairy Tales and Feminism: New Approaches.” Detroit: Wayne State University Press, (2004).

[5] Cixous, Hélène, and Catherine Clément. "The Newly Born Woman.” Translated by Betsy Wing. Minneapolis: University of Minnesota Press, (1986).

[6] Knowles, Murray, and Kirsten Malmkjær. "Language and Control in Children's Literature." London; New York: Routledge, (November 1996). doi: 10.4324/9780203419755.

[7] Lurie, Alison. “Don’t Tell the Grown-ups: The Subversive Power of Children's Literature.” Boston: Back Bay Books, (1998). 
[8] Hartsock, Nancy. "Foucault on Power: A Theory for Women?" In "Feminism/ Postmodernism.” Edited by Linda J. Nicholson, 157-75. New York: Routledge, (1990). doi: 10.4324/9780203699386.

[9] Macdonald, George. "The Princess and the Goblin." Adelaide: University of Adelaide, (2014). Available online: https://ebooks.adelaide.edu.au/m/macdonald/george/princess-and-the-goblin/chapter1.html (Accessed on 21 June 2019).

[10] Harries, Elizabeth Wanning. "Twice Upon a Time: Women Writers and the History of the Fairy Tale." Princeton, N.J.: Princeton University Press, (2001). doi: 10.2307/j.ctv36zqnq.13.

[11] Friedan, Betty. “The Feminine Mystique.” New York: Dell Publishing CO. INC., (1963).

[12] Berryman, John. "Five Young American Poets." Norfolk, Connecticut: New Directions, (1940).

[13] Rushdie, Salman. Introduction to "Burning Your Boats: The Collected Short Stories" by Angela Carter, ix-xiv. New York: Henry Holt, (1995).

[14] Morton, Richard Everett. “Anne Sexton's Poetry of Redemption: The Chronology of a Pilgrimage.” Lewiston, N.Y.: E. Mellen Press, (1988).

[15] Jones, Steven Swann. “On Analyzing Fairy Tales: ‘Little Red Riding Hood' Revisited.” Western Folklore 46, no. 2 (April 1987): 97. doi: $10.2307 / 1499927$.

[16] Kaiser, Mary. "Fairy Tale as Sexual Allegory: Intertextuality in Angela Carter's The Bloody Chamber". The Review of Contemporary Fiction 14, no. 3 (Fall 1994): 30-36. Available online: https://www.questia.com/library/journal/1G115906135/fairy-tale-as-sexual-allegory-intertextuality-in (Accessed on 21 June 2019).

[17] Croce, Arlene. “Is the Muse Dead?” New Yorker, February 26, (1996), 164-169.

[18] Gilbert, Sandra M., and Susan Gubar. "The Madwoman in the Attic: The Woman Writer and the Nineteenth-Century Literary Imagination.” New Haven: Yale Nota Bene, (2000).

[19] de Beauvoir, Simon. "The Second Sex." Translated by H. M. Parshley. London: Lowe and Brydone (Printers) LTD, (1956).

[20] Bartky, Sandra Lee. "Suffering to Be Beautiful." In "Gender Struggles: Practical Approaches to Contemporary Feminism." Edited by Constance L. Mui and Julien S. Murphy, 241-56. Lanham, MD: Rowman \& Littlefield Pub., (2002).

[21] Sexton, Anne. "The Complete Poems.” Boston: Houghton Mifflin, (1999).

[22] Chafetz, Janet Saltzman. "Gender Equity: An Integrated Theory of Stability and Change.” Newbury Park, Calif.: Sage. Publications, (1990).

[23] McGowan, Philip. “Anne Sexton and Middle Generation Poetry: The Geography of Grief.” Westport, Conn.: Praeger Publishers, (2004).

[24] Kaplan, Louise J. “Cultures of fetishism.” New York: Palgrave Macmillan, (2006).

[25] Wolff, Janet. "Feminine Sentences: Essays on Women and Culture." Cambridge: Polity. Press, (1990).

[26] Sexton, Anne. "With Patricia Marx," In "No Evil Star: Selected Essays, Interviews, and Prose.” Edited by Steven E. Colburn, 70-82. Ann Arbor: University of Michigan Press, (1985). doi:10.3998/mpub.7385.

[27] Bacchilega, Cristina. "Postmodern Fairy Tales: Gender and Narrative Strategies." Philadelphia: University of Pennsylvania Press, (1997).

[28] Carter, Angela. "The Bloody Chamber and Other Stories.” New York: Penguin Books, (2015).

[29] Lacan, Jacques. “The Four Fundamental Concepts of Psychoanalysis.” New York: W.W. Norton, (1998).

[30] Glapka, Ewa. “'If You Look at Me Like at a Piece of Meat, Then That's a Problem' - Women in the Center of the Male Gaze. Feminist Poststructuralist Discourse Analysis as a Tool of Critique.” Critical Discourse Studies 15, no. 1 (October 16, 2017): 87-103. doi:10.1080/17405904.2017.1390480.

[31] Horney, Karen. "Feminine Psychology.” New York; London: Norton, (1993).

[32] Jordan, Elaine. “The Dangers of Angela Carter.” In “Critical Essays on Angela Carter.” Edited by Lindsey Tucker, 33-45. New. York; G.K. Hall; London: Prentice Hall International, (1998).

[33] Irigaray, Luce. “This Sex which is Not One.” Ithaca, N.Y.: Cornell University Press, (1985).

[34] Bailly, Lionel. "Lacan: A Beginner's Guide.” Oxford: Oneworld, (2009).

[35] Bettelheim, Bruno. “The Uses of Enchantment: The Meaning and Importance of Fairy Tales.” New York: Vintage Books, (1977).

[36] Hall, Caroline King Barnard. “Anne Sexton.” Boston: Twayne Publishers, (1989).

[37] Gallop, Jane. “Reading Lacan.” Ithaca: Cornell University Press, (December 31, 2019). doi: 10.7591/9781501721601.

[38] Halson, Jacqui. "Young Women, Sexual Harassment and Heterosexuality: Violence, Power Relations and Mixed-Sex. Schooling." 
In “Gender, Power and Sexuality.” Edited by Pamela Abbott and Claire Wallace, 97-113. Houndmills, Basingstoke: Macmillan, (1991). doi: 10.1007/978-1-349-21241-5_6.

[39] Cashdan, Sheldon. “The Witch Must Die: The Hidden Meaning of Fairy Tales.” New York: Basic Books, (1999).

[40] Carter, Angela. "Notes from the Front Line." In "On Gender and Writing." Edited by Michelene Wandor, 69-77. London: Pandora Press, (1983).

[41] Lee, Alison. “Angela Carter.” New York: G.K. Hall, (1997).

[42] Day, Aidan. “Angela Carter: The Rational Glass.” Manchester: Manchester University Press, (1998).

[43] Bowden, Peta, and Jane Mummery. "Understanding Feminism.” Stocksfield U.K.: Acumen, (2009). doi:10.1017/UPO 9781844654451.

[44] Frayling, Christopher. "Inside the Bloody Chamber: On Angela Carter, the Gothic and Other Wierd Tales.” London: Oberon Books, (2015).

[45] Sexton, Anne. "With Barbara Kevles,” In "No Evil Star: Selected Essays, Interviews, and Prose.” Edited by Steven E. Colburn, 83-111. Ann Arbor: University of Michigan Press, (1985). doi: 10.3998/mpub.7385.

[46] Rich, Adrienne. "Blood, Bread, and Poetry: Selected Prose, 1979-1985.” New York: Norton, (1986). 